Synt hesi s of anal ogs of wasabi phyt oal exi $n$ ( net hyl 1- met hoxyi ndol e- 3-car boxyl at e)

\begin{tabular}{|c|c|}
\hline 著者 & $\begin{array}{l}\text { Yamada Koj i, Kanbayashi Yuki ko, Tom oka Saor i, } \\
\text { Somei Nasanor i }\end{array}$ \\
\hline $\begin{array}{l}\text { jour nal or } \\
\text { publ i cat i on title }\end{array}$ & Het er ocycl es \\
\hline vol une & 57 \\
\hline nunber & 9 \\
\hline page $r$ ange & 1627- 1634 \\
\hline year & 2002-09- 01 \\
\hline URL & ht t p: //hdl . handl e. net /2297/4372 \\
\hline
\end{tabular}




\title{
SYNTHESIS OF ANALOGS OF WASABI PHYTOALEXIN (METHYL 1-METHOXYINDOLE-3-CARBOXYLATE) ${ }^{1}$
}

\author{
Koji Yamada, Yukiko Kanbayashi, Saori Tomioka, and Masanori Somei* \\ Faculty of Pharmaceutical Sciences, Kanazawa University, \\ 13-1 Takara-machi, Kanazawa 920-0934, Japan
}

\begin{abstract}
Syntheses of wasabi phytoalexin analogs, such as 6-bromo-5-iodo, 2-bromo-5-iodo, 6-nitro, 5-chloroacetyl, and 6-chloroacetyl congeners, are reported. An interesting effect of the 1-methoxy group on the regioselectivity of electrophilic substitution reactions on indole nucleus is observed.
\end{abstract}

Indoles having a carboxy or a formyl group at the 3-position, including 1-hydroxy- or 1-methoxyindole derivatives, exhibit marked physiological activities in spite of their simple chemical structures. ${ }^{2}$ Compounds (1-3) ${ }^{2 a-d}$ are a few representative examples (Scheme 1). Brassicanal $A^{3}$ (4) and 1-methoxyindole-3-carbaldehyde ${ }^{3 a}(5)$ are additional examples isolated by Takasugi ${ }^{3}$ and co-workers as phytoalexins of plant family, Cruciferae. Recently, Pedras ${ }^{4}$ and co-workers determined methyl 1-methoxyindole-3-carboxylate (2b) as a phytoalexin of Wasabi (Wasabia japonica, syn. Eutrema wasabi).

We have been much interested in determining the effect of 1-methoxy and 1-hydroxy groups on both the chemical reactivities 5 and biological activities 6 of indole compounds, aiming at preparing our own biologically active substances. From these points of view, we needed various kinds of analogs 7 of wasabi phytoalexin like 6 and 7 as shown in general formula.

Figure 1

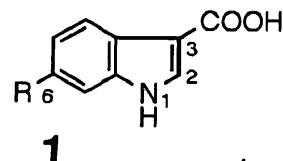

1

a) $R=\leadsto$

b) $\mathrm{R}=\mathrm{Br}$

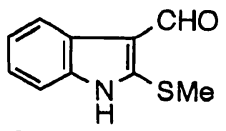

4

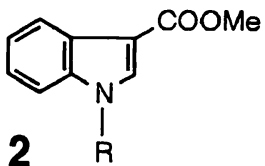

a) $\mathrm{R}=\mathrm{H}$

b) $\mathrm{R}=\mathrm{OMe}$

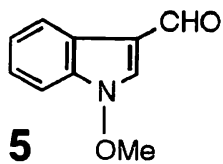

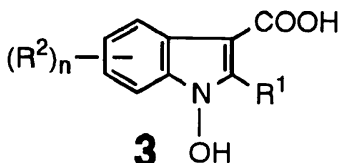

$\mathrm{R}^{1}=$ alkenyl, $N$-substituted $\alpha$-iminobenzyl, substituted arom., acyl groups

$R^{2}=$ halo, $n=0-4$<smiles>[X]c1cc2c(C(=O)O)c([Y])n(OC)c2cc1[X]</smiles>

$X^{1}, x^{2}, X^{3}=$ halogen $R=$ an appropriate substituent<smiles></smiles>

$\mathrm{R}^{1}=\mathrm{NO}_{2}, \mathrm{COR}, \quad$ I NHR, OR, etc. OMe 7 $R^{2}=$ an appropriate substituent

In the previous papers, ${ }^{7}$ we established simple synthetic method for $\mathbf{2 b}$ and its regioselective iodination to give methyl 5-iodo-1-methoxyindole-3-carboxylate $7 \mathrm{a}(\mathbf{8})$. Based on these results, synthesis of methyl 6-bromo-5-iodo-1-methoxyindole-3-carboxylate (9), a representative of 6, seemed to be easy. In fact, however, bromination of $\mathbf{8}$ gave complex mixtures of products under various reaction conditions. 
Relatively clean reaction took place with $\mathrm{Br}_{2}(1.3 \mathrm{~mol}$ eq. $)$ in $\mathrm{AcOH}$ at $100^{\circ} \mathrm{C}$ to provide 9, methyl 2-bromo-5-iodo-1-methoxyindole-3-carboxylate (10), 6-bromo- (11), 2-bromo-5-iodo-1-methoxyindole-3-carboxylic acid (12a), and 5-iodo-1-methoxyindole-3-carboxylic acid (13) in 17, 33, 6, 5, and $7 \%$ yields, respectively, together with $16 \%$ yield of unreacted $\mathbf{8}$. Since the carboxylic acids $(\mathbf{1 1}, \mathbf{1 2 a}$, and 13) were inseparable, the mixture was methylated with diazomethane $\left(\mathrm{CH}_{2} \mathrm{~N}_{2}\right)$ to give 9,10 , and 8 in 6,5 , and $7 \%$ yields, respectively. Assuming that the methylation proceeded in a quantitative yield, the yields of 11, 12a, and 13 in the initial bromination products were estimated. Pure compound (13) was obtained in $38 \%$ yield by reacting 8 with $15 \%$ aq. NaSMe. Under similar reaction conditions, 9 provided 11 and 14 in 45 and 38\% yields, respectively. In the same reaction of 10, the expected compound (12a) was not produced at all, instead nucleophilic substitution reaction by methyl sulfide occurred at the 2-position to afford $12 \mathrm{~b}$ in $83 \%$ yield. As a result, pure $12 \mathrm{a}$ has not been obtained yet.

On the other hand, bromination (1.3 mol eq.) of methyl 5-iodoindole-3-carboxylate (15) in $\mathrm{AcOH}$ at $100^{\circ} \mathrm{C}$ provided methyl 6-bromo- (16), 2,6-dibromo-5-iodoindole-3-carboxylate (17), and 6-bromo-5iodoindole-3-carboxylic acid (14) in 48,8 , and $17 \%$ yields, respectively. In the same reaction, when $0.85 \mathrm{~mol}$ eq. of bromine was employed, 16 and 14 were produced in 56 and $18 \%$ yields, respectively, without formation of $\mathbf{1 7}$. The structure of 14 was confirmed by the direct comparison with the sample obtained in $92 \%$ yield by the treatment of 16 with $15 \%$ NaSMe under reflux. Furthermore, methylation of 14 with $\mathrm{CH}_{2} \mathrm{~N}_{2}$ in $\mathrm{MeOH}$ provided 16 in $90 \%$ yield.

Above results exhibited that the bromination of $\mathbf{1 5}$ proceeds regioselectively at the 6-position, while the

\section{Scheme 1}

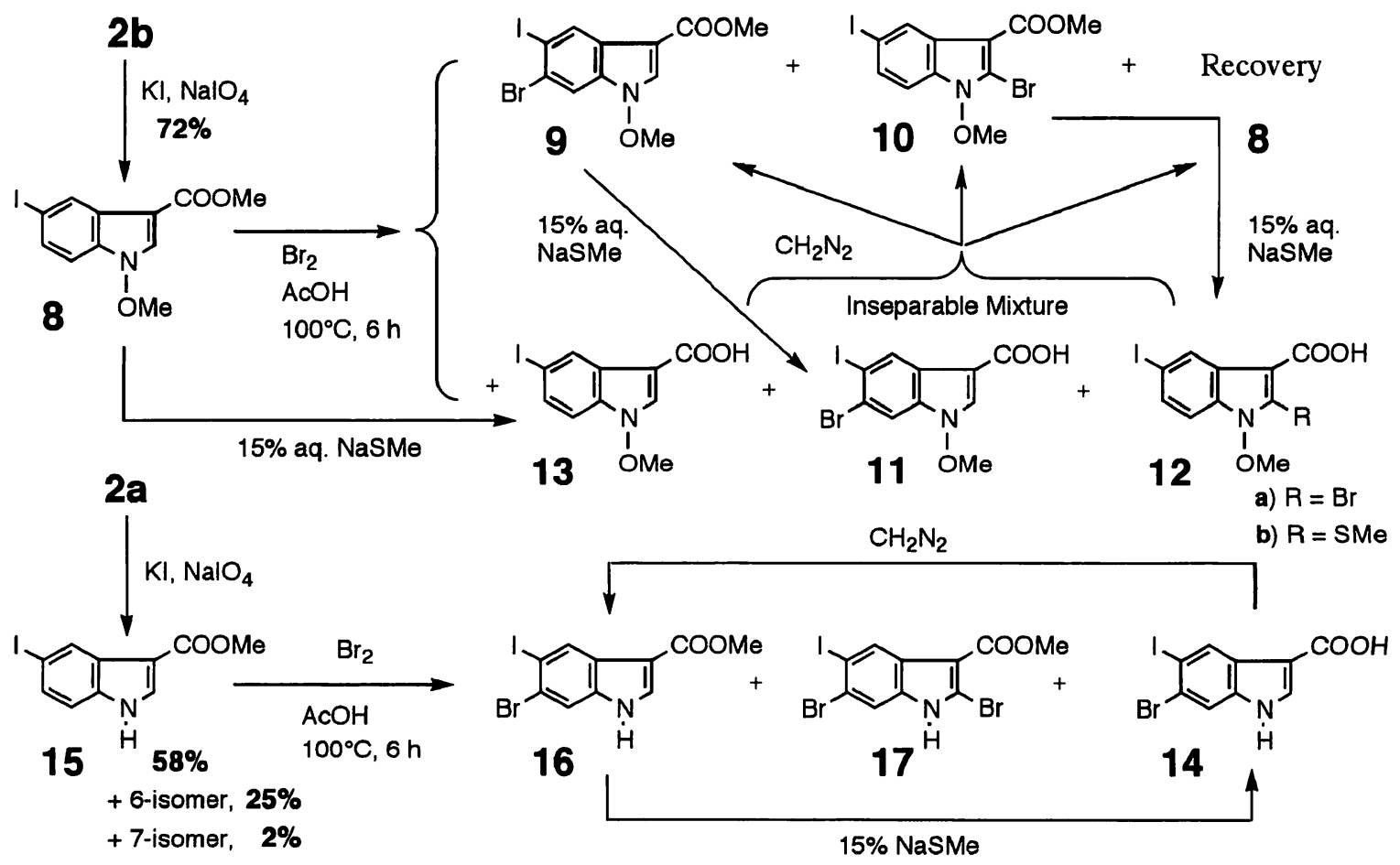


introduction of methoxy group into the 1-position of $\mathbf{1 5}$ alters the reaction site and tends to favor the 2-po- sition. These observations are quite interesting considering the initial iodination of $\mathbf{2 a}$ and $\mathbf{2 b}$. Thus, $\mathbf{2 b}$ produced $\mathbf{8}$ exclusively in $72 \%$ yield, $7 \mathrm{a}$ while $\mathbf{2 a}$ afforded $\mathbf{1 5}$ together with 6- and 7-iodo isomers in 58,25 , and $2 \%$ yields. 7 a Further reaction examples would be needed for clarifying the effect of 1-methoxy group on the regioselectivity of electrophilic substitution reactions.

We next tried the preparation of methyl 1-methoxy-6-nitroindole-3-carboxylate (18b, Scheme 2) as a common intermediate for $\mathbf{7}$, because the nitro group can easily be transformed into other functional groups such as amino, halogen, hydroxy, etc. According to our procedure, 8 1-methoxy-6-nitroindole (19) was prepared from an industrial raw material, 2,3-dihydroindole, in three steps in $71 \%$ overall yield. Subsequent Vilsmeier reaction of 19 with $\mathrm{POCl}_{3}$ and $N, N$-dimethylformamide provided a $94 \%$ yield of 1-methoxy-6-nitroindole-3-carbaldehyde (20), an analog of daikon phytoalexin 3 a (5). Oxidation of 20 to 1-methoxy-6-nitroindole-3-carboxylic acid (18a) was achieved in $92 \%$ yield by the treatment with $\mathrm{NaClO}_{2}{ }^{9}$ in the presence of 2-methyl-2-butene. Methylation of $18 \mathbf{a}$ with $\mathrm{CH}_{2} \mathrm{~N}_{2}$ in $\mathrm{MeOH}$ provided the desired $\mathbf{1 8 b}$ in $99 \%$ yield.

\section{Scheme 2}

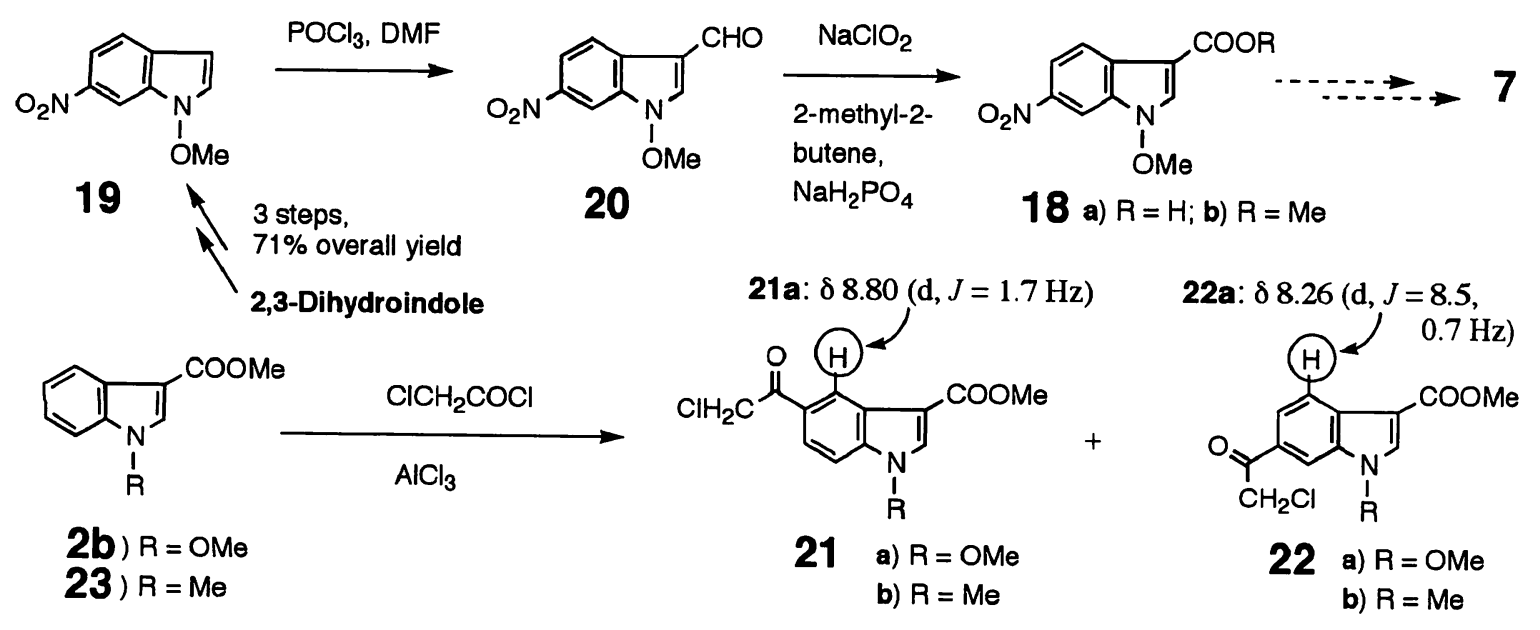

For the preparation of wasabi phytoalexin analogs having an acyl group, direct acylation of $\mathbf{2 b}$ was examined. Thus, Friedel-Crafts acylation using chloroacetyl chloride and $\mathrm{AlCl}_{3}$ in nitrobenzene at $100^{\circ} \mathrm{C}$ provided cleanly methyl 5-chloroacetyl- (21a) and 6-chloroacetyl-1-methoxyindole-3-carboxylate (22a) in 52 and $20 \%$ yields, respectively, and the ratio of $21 \mathbf{a}$ to $22 \mathbf{a}$ was $2.5: 1$. The acylated position of $21 \mathbf{a}$ is determined by the presence of $\mathrm{C} 4-\mathrm{H}$ signal at $8.80 \mathrm{ppm}(\mathrm{d}, J=1.7 \mathrm{~Hz})$ in its ${ }^{1} \mathrm{H}-\mathrm{NMR}$ spectrum, while the corresponding $\mathrm{C} 4-\mathrm{H}$ signal of $22 \mathrm{a}$ is observed at $8.26 \mathrm{ppm}(\mathrm{d}, J=8.5,0.7 \mathrm{~Hz}$ ) proving the 6-substituted indole structure.

Similar results were already reported by Nakatsuka 10 and co-workers in the chloroacetylation of methyl 1-methylindole-3-carboxylate (23). In their experiment, however, 21b and 22b were obtained as an 
inseparable mixture. Based on the ratio of the following Baeyer-Villiger oxidation products, the ratio of 21b to 22b could be estimated to be 3:1. Similar Friedel-Crafts acylation of indoles having an electron withdrawing group has been reported by several researchers. 11 Comparing these results, it would be safe to say that the introduction of a methoxy group into the 1-position prefers the 6-substitution to 5-substitution in Friedel-Crafts acylation.

In conclusion, introduction of a methoxy group into the 1-position is found to influence significantly the regiochemistry of electrophilic substitution reactions on indole nucleus. With key building blocks such as $9,10,15,18,21 a$, and 22a in hand, preparations of various kinds of wasabi phytoalexin analogs are now in progress to conduct structure-activity relationship study.

\section{EXPERIMENTAL}

Melting points were determined on a Yanagimoto micro melting point apparatus and are uncorrected. IR spectra were determined with a Horiba FT-720 spectrophotometer, and ${ }_{1}$ H-NMR spectra with a JEOL GSX-500 spectrometer with tetramethylsilane as an internal standard. MS spectra were recorded on a JEOL SX-102A spectrometer. Column chromatography was performed on silica gel $\left(\mathrm{SiO}_{2}, 100-200\right.$ mesh, from Kanto Chemical Co., Inc.) throughout the present study.

Methyl 6-Bromo- (9), 2-Bromo-5-iodo-1-methoxyindole-3-carboxylate (10), 6-Bromo(11), 2-Bromo- (12a), and 5-iodo-1-methoxyindole-3-carboxylic acid (13) from Methyl

5-Iodo-1-methoxyindole-3-carboxylate (8) - A solution of $\mathrm{Br}_{2}(3.8 \mathrm{~mL}, 0.76 \mathrm{mmol})$ in $\mathrm{AcOH}$ was added to a solution of $8(192.7 \mathrm{mg}, 0.58 \mathrm{mmol})$ in $\mathrm{AcOH}(10 \mathrm{~mL})$ and the mixture was heated at $100^{\circ} \mathrm{C}$ for $6 \mathrm{~h}$ with stirring under Ar atmosphere. After addition of $\mathrm{H}_{2} \mathrm{O}$ under ice cooling, the whole was extracted with $\mathrm{CHCl}_{3}-\mathrm{MeOH}(9: 1, \mathrm{v} / \mathrm{v})$. The extract was washed with brine, dried over $\mathrm{Na}_{2} \mathrm{SO}_{4}$, and evaporated under reduced pressure to leave an oil, which was column-chromatographed repeatedly on $\mathrm{SiO}_{2}$ with $\mathrm{CHCl}_{3}$-hexane $(1: 1, \mathrm{v} / \mathrm{v})$ and then with $\mathrm{CHCl}_{3}$ to give 10 (80 mg, 33\%), 9 (40.7 mg, 17\%), $8(30.1 \mathrm{mg}, 16 \%)$, and a mixture fraction $(11,12 \mathrm{a}$, and 13, $45.6 \mathrm{mg})$ in the order of elution. 9: $\mathrm{mp}$ $142.5-143.0^{\circ} \mathrm{C}$ (colorless fine needles, recrystallized from $\mathrm{CHCl}_{3}$-hexane). IR (KBr): 1695, 1517 , 1446, $1205 \mathrm{~cm}^{-1} .1_{\mathrm{H}-\mathrm{NMR}}\left(\mathrm{CDCl}_{3}\right)$ 8: $3.91(3 \mathrm{H}, \mathrm{s}), 4.14(3 \mathrm{H}, \mathrm{s}), 7.79(1 \mathrm{H}, \mathrm{s}), 7.90(1 \mathrm{H}, \mathrm{s}), 8.69$ $(1 \mathrm{H}, \mathrm{s})$. MS $m / z: 410\left(\mathrm{M}^{+}: \mathrm{Br}^{81}\right), 408\left(\mathrm{M}^{+}: \mathrm{Br}^{79}\right)$. Anal. Calcd for $\mathrm{C}_{11} \mathrm{H}_{9} \mathrm{NO}_{3} \mathrm{BrI}: \mathrm{C}, 32.22 ; \mathrm{H}, 2.21$; $\mathrm{N}$, 3.42. Found: $\mathrm{C}, 32.28 ; \mathrm{H}, 2.22 ; \mathrm{N}, 3.43 .10: \mathrm{mp} 158-159^{\circ} \mathrm{C}$ (colorless fine needles, recrystallized

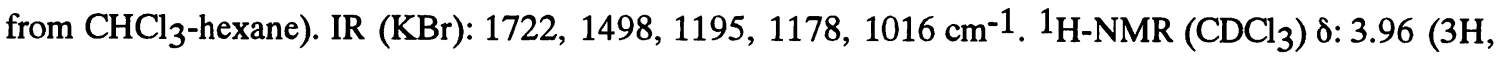
s), $4.14(3 \mathrm{H}, \mathrm{s}), 7.22(1 \mathrm{H}, \mathrm{d}, J=8.5 \mathrm{~Hz}), 7.59(1 \mathrm{H}, \mathrm{dd}, J=8.5,1.5 \mathrm{~Hz}), 8.50(1 \mathrm{H}, \mathrm{d}, J=1.5 \mathrm{~Hz}) . \mathrm{MS}$ $m / z: 410\left(\mathrm{M}^{+}: \mathrm{Br}^{81}\right), 408\left(\mathrm{M}^{+}: \mathrm{Br}{ }^{79}\right)$. Anal. Calcd for $\mathrm{C}_{11} \mathrm{H}_{9} \mathrm{NO}_{3} \mathrm{BrI} \cdot 1 / 2 \mathrm{H}_{2} \mathrm{O}: \mathrm{C}, 31.53 ; \mathrm{H}, 2.17 ; \mathrm{N}$, 3.34. Found: C, 31.21; H, 2.19; N, 3.28. Pure samples, (11) and (13), were obtained from 9 and 8 , respectively, by the reaction with $15 \%$ aq. NaSMe as shown below.

Separation of 11, 12a, and 13 as Methylated Products, (9), (10), and (8) - Excess $\mathrm{CH}_{2} \mathrm{~N}_{2}$ in $\mathrm{Et}_{2} \mathrm{O}$ was added to a solution of the mixture fraction $(11,12 \mathrm{a}$, and $13,45.6 \mathrm{mg}$ ), obtained in the above experiment, in $\mathrm{MeOH}(5.0 \mathrm{~mL})$ and the whole was stirred at $\mathrm{rt}$ for $10 \mathrm{~min}$. The solvent was evaporated under reduced pressure to leave an oil, which was column-chromatographed on $\mathrm{SiO}_{2}$ with $\mathrm{CHCl}_{3}$-hexane (1:2, v/v) to give 10 (11.9 mg, 5\%), 9 (14.0 mg, 6\%), and 8 (12.6 mg, 7\%). 
6-Bromo-5-Iodo-1-methoxyindole-3-carboxylic acid (11) and 14 from 9 - Excess $15 \%$ aq. $\mathrm{NaSMe}(8 \mathrm{~mL})$ was added to a solution of $9(51.8 \mathrm{mg}, 0.13 \mathrm{mmol})$ in $\mathrm{MeOH}(3 \mathrm{~mL})$ and the mixture was refluxed for $2 \mathrm{~h}$ with stirring under Ar atmosphere. After addition of $\mathrm{H}_{2} \mathrm{O}$ under ice cooling, the whole was made acidic $(\mathrm{pH} 1)$ by adding $8 \% \mathrm{HCl}$ and extracted with EtOAc. The extract was washed with brine, dried over $\mathrm{Na}_{2} \mathrm{SO}_{4}$, and evaporated under reduced pressure to leave a solid, which was column-chromatographed on $\mathrm{SiO}_{2}$ with $\mathrm{CHCl}_{3}-\mathrm{MeOH}-\mathrm{AcOH}(46: 1: 0.1, \mathrm{v} / \mathrm{v})$ to give $11(22.5 \mathrm{mg}, 45 \%)$ and $14(17.8 \mathrm{mg}, 38 \%)$ in the order of elution. 11: $\mathrm{mp} 275-280^{\circ} \mathrm{C}$ (decomp, colorless fine needles, recrystallized from $\left.\mathrm{CHCl}_{3}-\mathrm{MeOH}\right)$. IR $(\mathrm{KBr}): 1658,1520,1217 \mathrm{~cm}^{-1} .{ }^{1} \mathrm{H}-\mathrm{NMR}\left(5 \% \mathrm{CD}_{3} \mathrm{OD}\right.$ in

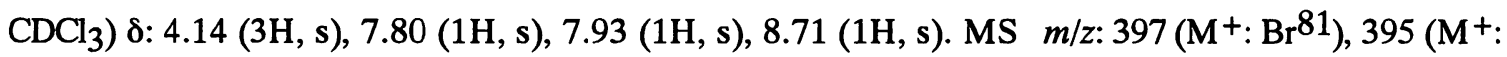
$\mathrm{Br}^{79}$ ). Anal. Calcd for $\mathrm{C}_{10} \mathrm{H}_{7} \mathrm{NO}_{3} \mathrm{BrI}: \mathrm{C}, 30.33 ; \mathrm{H}, 1.78 ; \mathrm{N}, 3.54$. Found: C, 30.54; H, $1.85 ; \mathrm{N}$, 3.52 .

\section{5-Iodo-1-methoxy-2-methylthioindole-3-carboxylic acid (12b) from 10 - Excess $15 \%$ aq.} $\mathrm{NaSMe}(2 \mathrm{~mL})$ was added to a solution of $10(23.8 \mathrm{mg}, 0.06 \mathrm{mmol})$ in $\mathrm{MeOH}(2 \mathrm{~mL})$ and the mixture was refluxed for $1 \mathrm{~h}$ with stirring under Ar atmosphere. After addition of $\mathrm{H}_{2} \mathrm{O}$ under ice cooling, the whole was made acidic ( $\mathrm{pH} 3$ ) by adding $8 \% \mathrm{HCl}$ and extracted with EtOAc-MeOH $(9: 1$, v/v). The extract was washed with brine, dried over $\mathrm{Na}_{2} \mathrm{SO}_{4}$, and evaporated under reduced pressure to leave a solid, which was column-chromatographed on $\mathrm{SiO}_{2}$ with $\mathrm{CHCl}_{3}-\mathrm{MeOH}-\mathrm{AcOH}(46: 1: 0.5$, v/v) to give $12 \mathrm{~b}\left(17.4 \mathrm{mg}, 83 \%\right.$ ). 12b: $\mathrm{mp} 167-168^{\circ} \mathrm{C}$ (decomp, colorless fine needles, recrystallized from $\mathrm{CHCl}_{3}$-hexane). IR (KBr): 1668, 1492, $1205 \mathrm{~cm}^{-1} .1_{\mathrm{H}-\mathrm{NMR}\left(\mathrm{CDCl}_{3}\right)}$ 8: $2.68(3 \mathrm{H}, \mathrm{s}), 4.16(3 \mathrm{H}, \mathrm{s})$, $7.21(1 \mathrm{H}, \mathrm{dd}, J=8.5,0.7 \mathrm{~Hz}), 7.61(1 \mathrm{H}, \mathrm{dd}, J=8.5,1.5 \mathrm{~Hz}), 8.62(1 \mathrm{H}$, dd, $J=1.5,0.7 \mathrm{~Hz})$. HighResolution MS m/z:: Calcd for $\mathrm{C}_{11} \mathrm{H}_{10} \mathrm{NO}_{3}$ IS: 362.9426 . Found: 362.9429 .

5-Iodo-1-methoxyindole-3-carboxylic acid (13) from 8 - Excess $15 \%$ aq. NaSMe $(5.0 \mathrm{~mL})$ was added to a solution of $8(32.2 \mathrm{mg}, 0.9 \mathrm{mmol})$ in $\mathrm{MeOH}(2 \mathrm{~mL})$ and the mixture was refluxed for $1 \mathrm{~h}$ with stirring under $\mathrm{Ar}$ atmosphere. After addition of $\mathrm{H}_{2} \mathrm{O}$ under ice cooling, the whole was made acidic (pH 3) by adding $8 \% \mathrm{HCl}$ and extracted with EtOAc-MeOH $(95: 5, \mathrm{v} / \mathrm{v})$. The extract was washed with brine, dried over $\mathrm{Na}_{2} \mathrm{SO}_{4}$, and evaporated under reduced pressure to leave a solid, which was columnchromatographed on $\mathrm{SiO}_{2}$ with $\mathrm{CHCl}_{3}-\mathrm{MeOH}-\mathrm{AcOH}(46: 1: 0.1, \mathrm{v} / \mathrm{v})$ to give 13 (11.7 mg, 38\%). 13: mp $211-213^{\circ} \mathrm{C}$ (colorless fine needles, recrystallized from $\mathrm{CHCl}_{3}$-hexane). IR (KBr): 1670,1525 , $1220 \mathrm{~cm}^{-1}$. ${ }^{1} \mathrm{H}-\mathrm{NMR}$ (DMSO-d $\left.)\right) \delta: 4.13(3 \mathrm{H}, \mathrm{s}), 7.42(1 \mathrm{H}, \mathrm{d}, J=8.6 \mathrm{~Hz}), 7.58(1 \mathrm{H}, \mathrm{dd}, J=8.6,1.7$ $\mathrm{Hz}), 8.35(1 \mathrm{H}, \mathrm{s}), 8.39(1 \mathrm{H}, \mathrm{d}, J=1.7 \mathrm{~Hz})$. MS m/z: $317\left(\mathrm{M}^{+}\right)$. Anal. Calcd for $\mathrm{C}_{10} \mathrm{H}_{8} \mathrm{NO}_{3} \mathrm{I} \cdot 1 / 2 \mathrm{H}_{2} \mathrm{O}$ : C, 36.83; H, 2.78; N, 4.30. Found: C, 36.95; H, 2.57; N, 4.35 .

Methyl 6-Bromo- (16), 2,6-Dibromo-5-iodoindole-3-carboxylate (17), and 6-Bromo-5iodoindole-3-carboxylic acid (14) from 15 - [Method 1] A solution of $\mathrm{Br}_{2}(2.2 \mathrm{~mL}, 0.43$ $\mathrm{mmol})$ in $\mathrm{AcOH}$ was added to a solution of $15(100.8 \mathrm{mg}, 0.33 \mathrm{mmol})$ in $\mathrm{AcOH}(5.0 \mathrm{~mL})$, and the mixture was heated at $100^{\circ} \mathrm{C}$ for $6 \mathrm{~h}$ with stirring under $\mathrm{Ar}$ atmosphere. After addition of $\mathrm{H}_{2} \mathrm{O}$ under ice cooling, the whole was extracted with $\mathrm{CHCl}_{3}-\mathrm{MeOH}(9: 1, \mathrm{v} / \mathrm{v})$. The extract was washed with brine, dried over $\mathrm{Na}_{2} \mathrm{SO}_{4}$, and evaporated under reduced pressure to leave an oil, which was columnchromatographed repeatedly on $\mathrm{SiO}_{2}$ with acetone-benzene $(1: 9, \mathrm{v} / \mathrm{v})$ and then with $\mathrm{CH}_{2} \mathrm{Cl}_{2}$-hexane $(2: 1$, $\mathrm{v} / \mathrm{v})$ to give $17(12.7 \mathrm{mg}, 8 \%), 16(61.5 \mathrm{mg}, 48 \%)$, and $14(20.5 \mathrm{mg}, 17 \%)$ in the order of elution. 16 : 
$\mathrm{mp} 262.5-263^{\circ} \mathrm{C}$ (colorless prisms, recrystallized from $\mathrm{MeOH}$ ). IR ( $\mathrm{KBr}$ ): $3270,1677,1520,1441$, 1198, $1053 \mathrm{~cm}^{-1}$. 1 ${ }_{\mathrm{H}-\mathrm{NMR}}$ (DMSO-d 6 ) $\delta: 3.82(3 \mathrm{H}, \mathrm{s}), 7.88(1 \mathrm{H}, \mathrm{s}), 8.12(1 \mathrm{H}, \mathrm{s}), 8.52(1 \mathrm{H}, \mathrm{s})$, $12.10\left(1 \mathrm{H}\right.$, br s, disappeared on addition of $\left.\mathrm{D}_{2} \mathrm{O}\right)$. MS m/z: $381\left(\mathrm{M}^{+}: \mathrm{Br}^{81}\right), 279\left(\mathrm{M}^{+}: \mathrm{Br}^{79}\right)$. Anal. Calcd for $\mathrm{C}_{10} \mathrm{H}_{7} \mathrm{NO}_{2} \mathrm{BrI}$ : C, 31.61; $\mathrm{H}, 1.86 ; \mathrm{N}, 3.69$. Found: $\mathrm{C}, 31.74 ; \mathrm{H}, 1.73 ; \mathrm{N}, 3.74 .17: \mathrm{mp}$ $275-277^{\circ} \mathrm{C}$ (colorless fine needles, recrystallized from $\mathrm{CHCl}_{3}-\mathrm{MeOH}$ ). IR (KBr): 3226, 1681, 1504, 1430, 1382, $1062 \mathrm{~cm}^{-1}$. 1H-NMR (DMSO-d 6 ) $\delta: 3.85(3 \mathrm{H}, \mathrm{s}), 7.74(1 \mathrm{H}, \mathrm{s}), 8.47(1 \mathrm{H}, \mathrm{s}), 13.05(1 \mathrm{H}$, br s, disappeared on addition of $\left.\mathrm{D}_{2} \mathrm{O}\right)$. MS $m / z$ : $460\left(\mathrm{M}^{+}: 2 \times \mathrm{Br}^{81}\right), 458\left(\mathrm{M}^{+}: \mathrm{Br}^{81}, \mathrm{Br}^{79}\right), 456\left(\mathrm{M}^{+}: 2\right.$ $x \mathrm{Br}^{79}$ ). Anal. Calcd for $\mathrm{C}_{10} \mathrm{H}_{6} \mathrm{NO}_{2} \mathrm{Br}_{2} \mathrm{I} \cdot 1 / 4 \mathrm{H}_{2} \mathrm{O}: \mathrm{C}, 25.92 ; \mathrm{H}, 1.41 ; \mathrm{N}, 3.02$. Found: C, 25.80; $\mathrm{H}$, 1.44; N, 2.95. 14: $\mathrm{mp} 224-226^{\circ} \mathrm{C}$ (decomp, brown prisms, recrystallized from EtOAc-MeOH). IR (KBr): 3249, 1637, 1531, $1186 \mathrm{~cm}^{-1}$. 1 $\mathrm{H}-\mathrm{NMR}$ (DMSO-d 6 ) 8: $7.85(1 \mathrm{H}, \mathrm{s}), 8.02(1 \mathrm{H}, \mathrm{s}), 8.54(1 \mathrm{H}$, s), $11.96\left(1 \mathrm{H}\right.$, br s, disappeared on addition of $\left.\mathrm{D}_{2} \mathrm{O}\right)$. MS $m / z: 367\left(\mathrm{M}^{+}: \mathrm{Br}^{81}\right), 365\left(\mathrm{M}^{+}: \mathrm{Br}^{79}\right)$. Anal. Calcd for $\mathrm{C}_{9} \mathrm{H}_{5} \mathrm{NO}_{2} \mathrm{BrI} \cdot 1 / 2 \mathrm{H}_{2} \mathrm{O}: \mathrm{C}, 28.82 ; \mathrm{H}, 1.61 ; \mathrm{N}, 3.74$. Found: C, 28.68; H, 1.51; N,3.67.

[Method 2] A solution of $\mathrm{Br}_{2}$ in $\mathrm{AcOH}(1.5 \mathrm{~mL}, 0.30 \mathrm{mmol})$ was added to a solution of 15 (108.3 mg, $0.36 \mathrm{mmol})$ in $\mathrm{AcOH}(5.0 \mathrm{~mL})$, and the mixture was heated at $100^{\circ} \mathrm{C}$ for $6 \mathrm{~h}$ with stirring under $\mathrm{Ar}$ atmosphere. After the same work-up and column-chromatography as described in the [Method 1], 16 (76.9 $\mathrm{mg}, 56 \%)$ and $14(23.8 \mathrm{mg}, 18 \%)$ were obtained.

Methyl 6-Bromo-5-iodoindole-3-carboxylate (16) from $14-$ Excess $\mathrm{CH}_{2} \mathrm{~N}_{2}$ in $\mathrm{Et}_{2} \mathrm{O}$ was added to a solution of $14(13.0 \mathrm{mg}, 0.036 \mathrm{mmol})$ in $\mathrm{MeOH}(10 \mathrm{~mL})$ and the mixture was stirred at $\mathrm{rt}$ for $30 \mathrm{~min}$. The solvent was evaporated under reduced pressure to leave a solid, which was column-chromatographed on $\mathrm{SiO}_{2}$ with $\mathrm{CHCl}_{3}-\mathrm{MeOH}(95: 5, \mathrm{v} / \mathrm{v})$ to give 16 (12.1 mg, 90\%).

6-Bromo-5-iodoindole-3-carboxylic acid (14) from 16 - Excess $15 \%$ aq. NaSMe $(8.0 \mathrm{~mL})$ was added to a suspension of $16(50.9 \mathrm{mg}, 0.13 \mathrm{mmol})$ in $\mathrm{MeOH}(3 \mathrm{~mL})$ and the mixture was refluxed for $2 \mathrm{~h}$ with stirring under $\mathrm{Ar}$ atmosphere. After addition of $\mathrm{H}_{2} \mathrm{O}$ under ice cooling, the whole was made acidic (pH 3) by adding $8 \% \mathrm{HCl}$ and extracted with $\mathrm{CHCl}_{3}-\mathrm{MeOH}(9: 1, \mathrm{v} / \mathrm{v})$. The extract was washed with brine, dried over $\mathrm{Na}_{2} \mathrm{SO}_{4}$, and evaporated under reduced pressure to leave a solid, which was column-chromatographed on $\mathrm{SiO}_{2}$ with $\mathrm{CHCl}_{3}-\mathrm{MeOH}(95: 5, \mathrm{v} / \mathrm{v})$ to give 14 (45.3 mg, 92\%).

1-Methoxy-6-nitroindole-3-carboxylic acid (18a) from 20 - A solution of sodium chlorite $(1.186 \mathrm{~g}, 13.1 \mathrm{mmol})$ and sodium dihydrogen phosphate $(1.535 \mathrm{~g}, 9.84 \mathrm{mmol})$ in $\mathrm{H}_{2} \mathrm{O}(6 \mathrm{~mL})$ was added to a solution of $20(144.4 \mathrm{mg}, 0.66 \mathrm{mmol})$ and 2-methyl-2-butene $(3.0 \mathrm{~mL})$ in DMF $(10 \mathrm{~mL})$, and the mixture was stirred at $\mathrm{rt}$ for $1.5 \mathrm{~h}$. The whole was made acidic $(\mathrm{pH} 3)$ by adding $8 \% \mathrm{HCl}$ under ice cooling, and extracted with EtOAc. The extract was washed with brine, dried over $\mathrm{Na}_{2} \mathrm{SO}_{4}$, and evaporated under reduced pressure to leave a solid, which was column-chromatographed on $\mathrm{SiO}_{2}$ with $\mathrm{CHCl}_{3}$ $\mathrm{MeOH}-\mathrm{AcOH}(46: 1: 0.1, \mathrm{v} / \mathrm{v})$ to give $18 \mathbf{a}(143.2 \mathrm{mg}, 92 \%)$. 18a: $\mathrm{mp} 232.5-233^{\circ} \mathrm{C}$ (pale yellow fine needles, recrystallized from $\mathrm{CHCl}_{3}$-hexane). IR (KBr): $1682,1516,1348,1221 \mathrm{~cm}^{-1}$. ${ }_{1} \mathrm{H}-\mathrm{NMR}$ (DMSO- $\left.d_{6}\right)$ 8: $4.23(3 \mathrm{H}, \mathrm{s}), 8.11(1 \mathrm{H}, \mathrm{dd}, J=9.0,2.0 \mathrm{~Hz}), 8.24(1 \mathrm{H}, \mathrm{d}, J=9.0 \mathrm{~Hz}), 8.46(1 \mathrm{H}, \mathrm{d}, J$ $=2.0 \mathrm{~Hz}), 8.77(1 \mathrm{H}, \mathrm{s})$. MS m/z: $236\left(\mathrm{M}^{+}\right)$. Anal. Calcd for $\mathrm{C}_{10} \mathrm{H}_{8} \mathrm{~N}_{2} \mathrm{O}_{5}: \mathrm{C}, 50.85 ; \mathrm{H}, 3.41 ; \mathrm{N}$, 11.86. Found: C, 50.64; H, 3.40; N, 11.83 .

Methyl 1-Methoxy-6-nitroindole-3-carboxylate (18b) from 18a - Excess $\mathrm{CH}_{2} \mathrm{~N}_{2}$ in $\mathrm{Et}_{2} \mathrm{O}$ was added to a suspension of $18 \mathbf{a}(11.1 \mathrm{mg}, 0.047 \mathrm{mmol})$ in $\mathrm{MeOH}(2.0 \mathrm{~mL})$ and the mixture was 
stirred at $\mathrm{rt}$ for $15 \mathrm{~min}$. After evaporation of the solvent under reduced pressure, the residue was columnchromatographed on $\mathrm{SiO}_{2}$ with $\mathrm{CHCl}_{3}$-hexane $(2: 1, \mathrm{v} / \mathrm{v})$ to give $18 \mathbf{b}$ (11.6 mg, 99\%). 18b: mp $155.5-156^{\circ} \mathrm{C}$ (pale yellow fine needles, recrystallized from $\mathrm{CHCl}_{3}$-hexane). IR (KBr): 1716,1514 , $1352,1213 \mathrm{~cm}^{-1} .1_{\mathrm{H}-\mathrm{NMR}}\left(\mathrm{CDCl}_{3}\right) \delta: 3.94(3 \mathrm{H}, \mathrm{s}), 4.23(3 \mathrm{H}, \mathrm{s}), 8.16(1 \mathrm{H}, \mathrm{dd}, J=9.0,2.0 \mathrm{~Hz}), 8.18$ $(1 \mathrm{H}, \mathrm{s}), 8.28(1 \mathrm{H}, \mathrm{d}, J=9.0 \mathrm{~Hz}), 8.43(1 \mathrm{H}, \mathrm{d}, J=2.0 \mathrm{~Hz})$. MS $m / z: 250\left(\mathrm{M}^{+}\right)$. Anal. Calcd for $\mathrm{C}_{11} \mathrm{H}_{10} \mathrm{~N}_{2} \mathrm{O}_{5} \cdot 1 / 8 \mathrm{H}_{2} \mathrm{O}: \mathrm{C}, 52.33 ; \mathrm{H}, 4.09 ; \mathrm{N}, 11.10$. Found: $\mathrm{C}, 52.21 ; \mathrm{H}, 4.05 ; \mathrm{N}, 11.11$.

1-Methoxy-6-nitroindole-3-carbaldehyde (20) from 1-Methoxy-6-nitroindole (19) $\mathrm{POCl}_{3}(0.97 \mathrm{~mL}, 10.4 \mathrm{mmol})$ was added to dry DMF $(5.8 \mathrm{~mL}, 63 \mathrm{mmol})$ at $0^{\circ} \mathrm{C}$ and stirring was continued for $15 \mathrm{~min}$. A solution of $19(1.00 \mathrm{~g}, 5.2 \mathrm{mmol})$ in dry DMF (15 mL) was added to the resultant mixture at $0^{\circ} \mathrm{C}$. After stirring at $\mathrm{it}$ for $7 \mathrm{~h}, \mathrm{H}_{2} \mathrm{O}$ was added to the reaction mixture at $0^{\circ} \mathrm{C}$ and the whole was made basic ( $\mathrm{pH} \mathrm{10}$ ) by adding sat. aq. $\mathrm{NaHCO}_{3}$. After stirring at $\mathrm{rt}$ for $30 \mathrm{~min}$ maintaining $\mathrm{pH} 10$ by adding sat. aq. $\mathrm{NaHCO}_{3}$, the whole was extracted with EtOAc. The extract was washed with brine, dried over $\mathrm{Na}_{2} \mathrm{SO}_{4}$, and evaporated under reduced pressure to leave yellow solid, which was columnchromatographed on $\mathrm{SiO}_{2}$ with EtOAc-hexane $(1: 2, \mathrm{v} / \mathrm{v})$ to give 20 (1.08 g, 94\%). 20: $\mathrm{mp} 180-182^{\circ} \mathrm{C}$ (yellow prisms, recrystallized from $\mathrm{CHCl}_{3}$-hexane). IR (KBr): 1664, 1653, 1508, $1342 \mathrm{~cm}-1$. ${ }^{1} \mathrm{H}-\mathrm{NMR}$ $\left(\mathrm{CDCl}_{3}\right)$ 8: $4.28(3 \mathrm{H}, \mathrm{s}), 8.14(1 \mathrm{H}, \mathrm{s}), 8.22(1 \mathrm{H}, \mathrm{dd}, J=8.8,2.0 \mathrm{~Hz}), 8.43(1 \mathrm{H}, \mathrm{d}, J=8.8 \mathrm{~Hz}), 8.45$ $(1 \mathrm{H}, \mathrm{d}, J=2.0 \mathrm{~Hz}), 10.02(1 \mathrm{H}, \mathrm{s})$. Anal. Calcd for $\mathrm{C}_{10} \mathrm{H}_{8} \mathrm{~N}_{2} \mathrm{O}_{4}: \mathrm{C}, 54.55 ; \mathrm{H}, 3.66 ; \mathrm{N}, 12.72$. Found: C, 54.32; H, 3.61; N, 12.54 .

Methyl 5-Chloroacetyl- (21a) and Methyl 6-Chloroacetyl-1-methoxyindole-3-carboxylate (22a) from $2 \mathbf{b}$ - Anhydrous $\mathrm{AlCl}_{3}(392.7 \mathrm{mg}, 2.94 \mathrm{mmol})$ and then a solution of chloroacetyl chloride $(166.1 \mathrm{mg}, 1.47 \mathrm{mmol})$ in nitrobenzene $(0.4 \mathrm{~mL})$ was added successively to a solution of $\mathbf{2 b}$ $(100.5 \mathrm{mg}, 0.49 \mathrm{mmol})$ in nitrobenzene $(1 \mathrm{~mL})$ and the mixture was heated at $100^{\circ} \mathrm{C}$ for 15 min with stirring. After addition of $\mathrm{H}_{2} \mathrm{O}$ with stirring under ice cooling, the solvent was evaporated under reduced pressure. The residue was made basic ( $\mathrm{pH} 11$ ) by adding $8 \% \mathrm{NaOH}$ and extracted with $\mathrm{CHCl}_{3}$. The extract was washed with brine, dried over $\mathrm{Na}_{2} \mathrm{SO}_{4}$, and evaporated under reduced pressure to leave an oil, which was column-chromatographed repeatedly on $\mathrm{SiO}_{2}$ with $\mathrm{CH}_{2} \mathrm{Cl}_{2}$ and $\mathrm{CHCl}_{3}$ to give $22 \mathbf{a}$ (26.9 $\mathrm{mg}, 20 \%$ ) and $21 \mathrm{a}$ (71.3 $\mathrm{mg}, 52 \%$ ) in the order of elution. 21a: $\mathrm{mp} 138-139^{\circ} \mathrm{C}$ (pale brown prisms, recrystallized from $\mathrm{CHCl}_{3}$-hexane). IR (KBr): $1700,1610,1218,1178 \mathrm{~cm}^{-1} .1_{\mathrm{H}-\mathrm{NMR}}\left(\mathrm{CDCl}_{3}\right) \delta$ : $3.95(3 \mathrm{H}, \mathrm{s}), 4.18(3 \mathrm{H}, \mathrm{s}), 4.84(2 \mathrm{H}, \mathrm{s}), 7.55(1 \mathrm{H}, \mathrm{dd}, J=8.7,1.0 \mathrm{~Hz}), 8.01(1 \mathrm{H}, \mathrm{dd}, J=8.7,1.7 \mathrm{~Hz})$, $8.03(1 \mathrm{H}, \mathrm{s}), 8.80(1 \mathrm{H}, \mathrm{d}, J=1.7 \mathrm{~Hz})$. MS $m / z: 283\left(\mathrm{M}^{+}: \mathrm{Cl}^{37}\right), 281\left(\mathrm{M}^{+}: \mathrm{Cl}^{35}\right)$. Anal. Calcd for $\mathrm{C}_{13} \mathrm{H}_{12} \mathrm{NO}_{4} \mathrm{Cl} \cdot 1 / 8 \mathrm{H}_{2} \mathrm{O}: \mathrm{C}, 54.99 ; \mathrm{H}, 4.35 ; \mathrm{N}, 4.96$. Found: $\mathrm{C}, 54.83 ; \mathrm{H}, 4.29 ; \mathrm{N}, 4.84 .22 \mathrm{a}: \mathrm{mp}$ $156-158^{\circ} \mathrm{C}$ (colorless prisms, recrystallized from $\mathrm{CHCl}_{3}$-hexane). IR (KBr): $1695,1616,1437,1387$, $1197 \mathrm{~cm}^{-1} .1_{\mathrm{H}-\mathrm{NMR}}\left(\mathrm{CDCl}_{3}\right)$ 8: $3.93(3 \mathrm{H}, \mathrm{s}), 4.21(3 \mathrm{H}, \mathrm{s}), 4.79(2 \mathrm{H}, \mathrm{s}), 7.85(1 \mathrm{H}, \mathrm{dd}, J=8.5,1.5$ $\mathrm{Hz}), 8.12(1 \mathrm{H}, \mathrm{s}), 8.16(1 \mathrm{H}, \mathrm{dd}, J=1.5,0.7 \mathrm{~Hz}), 8.26(1 \mathrm{H}, \mathrm{dd}, J=8.5,0.7 \mathrm{~Hz})$. High Resolution MS $m / z$ : Calcd. for $\mathrm{C}_{13} \mathrm{H}_{12} \mathrm{NO}_{4} \mathrm{Cl}: 283.0425\left(\mathrm{M}^{+}: \mathrm{Cl}^{37}\right)$ and $281.0455\left(\mathrm{M}^{+}: \mathrm{Cl}^{35}\right)$. Found: 283.0427 and 281.0427 .

\section{REFERENCES AND NOTES}

1. a) This report is Part 115 of a series entitled "The Chemistry of Indoles". b) Part 114: K. Yamada, F. 
Yamada, and M. Somei, Heterocycles, 2002, 57, 1231.

2. a) N. Zelikovitch, Z. Eyal, and Y.Kashman, Phytopathology, 1992, 8 2, 275; b) W. R. Schleigh and T. R. Welter, Eur. Pat. Appl. Ep 470,665 (Chem. Abstr., 1992, 116, 250503n). c) J. Jensen, U. Anthoni, C. Christophersen, and P. H. Nielsen, 1993, J. Nat. Prod., 56, 1553; d) M. Sakurai, J. Kawano, and N. Nakanishi, J. Antibiotics, 2001, 54, 628; e) L. M. Levy, G. M. Gabrera, J. E. Wright, and A. M. Seldes, Phytochemistry, 2000, 54, 941; f) J. -F. Hu, D. Wunderlich, I. Sattler, A. Härtl, I. Papastavrou, S. Grond, S. Grabley, X. -Z. Feng, and R. Thiericke, J. Antibiot., 2000, 53, 944.

3. a) M. Takasugi, K. Monde, N. Katsui, and A. Shirota, Symposium Papers, The 29th Symposium on The Chemistry of Natural Products, Sapporo, Aug. 1987, p. 629; b) M. Takasugi, K. Monde, N. Katsui, and A. Shirata, Bull. Chem. Soc. Japan, 1988, 61, 285; M. Somei, T. Kawasaki, Y. Fukui, F. Yamada, T. Kobayashi, H. Aoyama, and D. Shinmyo, Heterocycles, 1992, 61, 1877; M. Takasugi, Kagaku to Seibutu, 1993, 31, 22 and references cited therein.

4. M. S. C. Pedras and J. L. Sorensen, Phytochemistry, 1998, 49, 1959.

5. Review: M. Somei, Heterocycles, 1999, 50, 1157.

6. M. Somei, K. Yamada, M. Hasegawa, M. Tabata, Y. Nagahama, H. Morikawa, and F. Yamada, Heterocycles, 1996, 43, 1855; M. Somei, K. Noguchi, R. Yamagami, Y. Kawada, K. Yamada, and F. Yamada, ibid., 2000, 53, 7.

7. a) M. Somei, A. Tanimoto, H. Orita, F. Yamada, T. Ohta, Heterocycles, 2001, 54, 425. The yield of 8 from 2 b was improved to $72 \%$. b) F. Yamada, K. Yamada, H. Takeda, and M. Somei, ibid., 2001, 5 5, 2361.

8. K. Yamada, T. Kawasaki, Y. Fujita, and M. Somei, Heterocycles, 2001, 5 5, 1151.

9. A. Inada, Y. Nakamura, and Y. Morita, Chemistry Lett., 1980, 1287; M. Somei and Y. Saida, Heterocycles, 1985, 23, 3113; M. Somei, Y. Saida, T. Funamoto, and T. Ohta, Chem. Pharm. Bull., 1987, 35, 3146.

10. S. Nakatsuka, O. Asano, K. Ueda, and T. Goto, Heterocycles, 1987, 2 6, 1471.

11. T. Hino, Y. Torisawa, and M. Nakagawa, Chem. Pharm. Bull., 1982, 30, 2349; M. Tani, T. Aoki, S. Ito, S. Matsumoto, M. Hideshima, K. Fukushima, R. Nozawa, T. Maeda, M. Tashiro, Y. Yokoyama, and Y. Murakami, ibid., 1990, 38, 3261 and references cited therein. 